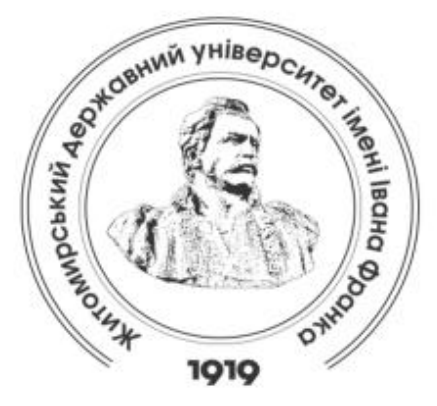

Zhytomyr Ivan Franko State University Journal. Pedagogical Sciences. Vol. 3 (102)

Вісник Житомирського державного університету імені Івана Франка. Педагогічні науки. Вип. 3 (102)

ISSN (Print): 2663-6387

ISSN (Online): 2664-0155

\title{
UDC 373.5.016:81'243 \\ DOI 10.35433/pedagogy.3(102).2020.114-130 \\ MOBILE LEARNING AS A COMPONENT OF THE FOREIGN LANGUAGE LEARNING PROCESS FOR SENIOR SCHOOL STUDENTS
}

\section{V. Vlasiuk ${ }^{*}$}

The article deals with the directions of using mobile education in modern educational system. It is noted that the use of "mobile-learning" will create more natural conditions for learning and optimizing the process of language training of high school students. Mobile learning is closely linked to e-learning and distance learning, the difference between which is the use of mobile devices, and in which students anywhere and at any time can develop and improve skills and abilities to speak a foreign language (based on the means of synchronous and asynchronous communication), to form sociocultural and intercultural competencies in order to use a foreign language as a means of communication in the social sphere. The work defines the term "mobile learning", its methodological foundations and the guiding principles for constructing a learning process, based on the usage of mobile devices. The analysis of the articles which are related to the use of mobile devices in teaching and their didactic functions is carried out. The advantages and disadvantages of this type of training, possibilities and features of introduction of mobile education in general educational schools are analyzed. The methodical potential of mobile technologies is considered and it is noted that if properly used, they can be didactic means, which helps to learn more foreign language more quickly and qualitatively, in comparison with traditional means. The main possibilities of using mobile gadgets in teaching activity during visualization of a demonstration material, questioning, testing, and also during distance learning are considered. The systematic use of mobile devices is indicated in order to increase the efficiency of the educational process. The necessity of combining the usage of mobile devices with traditional methods of training is substantiated. Prospects for the study of this topic in the future are described.

It is concluded that the introduction of mobile learning contributes to the implementation of personality-oriented foreign language learning, improving research skills of students, as well as the development of teamwork and cooperation skills, which will contribute to the formation of foreign language communicative competence of students.

Key words: mobile learning, mobile devices, mobile technologies, memory cards, creativity, mobile tools, smartphone, mobile applications.

\footnotetext{
* PhD Student

(Ternopil Volodymyr Hnatiuk National Pedagogical University)

Teacher of English and German

(TNVK "School-collegium by Patriarch Josyf Slipyi")

vlasiukvi@outlook.com

ORCID: 0000-0002-6862-697X
} 


\section{МОБІАЬНЕ НАВЧАННЯ ЯК СКААДОВА ПРОЦЕСУ ВИВЧЕННЯ IНОЗЕМНОÏ МОВИ ДИЯ УЧНІВ СТАРШОÏ ШКОАИ}

\section{B. BAacrok}

У статті розглядаються напрями використання мобільного навчання в сучасній освіті. Відзначається, шео застосування "тоbile-learning" дозволить створити більи природні умови для навчання та оптимізаиї проиесу мовної підготовки учнів старшої школи. Мобільне навчання тісно пов'язане з електронним та дистаниійним навчанням, відмінністю якого є використання мобільних пристроїв, а також при якому учні в будьякому місиі $i$ в будь-який час можуть розвивати і вдосконалювати навички та вміння володіння іноземною мовою (на основі засобів синхронної $i$ асинхронної комунікації), формувати соиіокультурну та міжкультурну компетениії з метою використання іноземної мови як засобу спілкування в соціально-побутовій сфрері. У роботі подано визначення терміну "мобільне навчання", його методологічні основи та провідні приниипи побудови проиесу навчання. на основі використання мобільних пристроїв. Виконано аналіз робіт, пов'язаних з застосування мобільних пристроїв в навчанні та їх дидактичним функиіям. Проаналізовано переваги та недоліки иъого виду навчання, можливості та особливості впровадження мобільного навчання у загально освітніх школах. Розглянуто методичний потениіал мобільних технологій та відзначено, шо при правильному їх застосуванню, вони можуть бути дидактичним засобом, шо сприяе більш швидкому $i$ якісному, в порівнянні з традиційними засобами, навчанню іншомовного спілкування. Розглянуто основні можливості використання мобільних гаджетів у навчальній діяльності під иас візуалізаиії демонстраиійного матеріалу, анкетування, тестування, а також під час дистаниійного навчання. Зазначено системність використання мобільних девайсів із метою підвищення ефективності освітнього проиесу. Обтрунтовано необхідність поєднання застосування мобільних пристроїв з традииійними методами навчання. Описано перспективи дослідження иієї теми в подальшому.

Зроблено висновки, що упровадження мобільного навчання сприяе реалізаиіі особистісно-орієнтованого навчання іноземної мови, удосконаленню науково-дослідних умінь учнів, а також розвитку навичок командної роботи та співпраці, що сприятиме формуванню іншомовної комунікативної компетениї школярів.

Ключові слова: мобільне навчання, мобільні пристрої, мобільні технологї̈, карти пам'яті, креативність, мобільні засоби, смартфон, мобільні додатки.

Introduction of the issue. We live in a mobile world, nevertheless it is further enhanced by the rapid proliferation of easy-to-use and relatively inexpensive smartphones, ebooks, tablets, and the release of specialized software for them. Modern mobile devices are multifunctional. One of the functions is access to content and learning.

The development of pedagogy in the XXI century is closely linked to technological progress and is characterized by the widespread use of information and communication technologies. The use of Internet resources has become an integral part of the teaching of any subject, and it has become a key component of foreign language learning process. The World Wide Web provides unlimited opportunities to use authentic materials of various kinds. The term "mobile learning" (m-learning) refers to the use of mobile and portable IT devices, such as PDAs, mobile phones and tablets, in teaching and learning.

Mobile learning is closely linked to elearning and distance learning, which is characterized by the use of mobile devices, and which also means that students anywhere and at any time can develop and improve foreign language skills and abilities (based on the means of synchronous and asynchronous communication), to form socio-cultural and intercultural competencies in order to use a foreign language as a means of 
communication in the social sphere. One of the most common mobile devices among young people is a smartphone. According to statistics, every year the number of smartphone users increases [4], and among young people their popularity is generally difficult to overestimate. Thus, the question arises as to how to use mobile phones, smartphones and tablets rationally and efficiently in class. But despite the availability of mobile phones among pupils and students, mobile learning is underused in the process of acquiring knowledge. Self-directed learning, flexibility and instant access to information are the main features of mobile learning. While learning a foreign language, portable and mobile devices are used not only to receive and process information, but also for continuous learning, such as the use of electronic dictionaries, books, audio and video support, as well as other language learning tools.

Current state of the issue. According to scientists, mobile learning is a natural evolution of e-learning or a new form of distance learning. In addition, scientists believe that mobile devices are a common tool that promotes a meaningful combination of work, study and leisure (T. Georgiev, J. Tuymala,

H. Turunen, A. Mostahdemin-Hossein, etc.). We agree with the opinion of scientists who have repeatedly covered the theoretical aspects of mobile learning in their works (domestic: S. Semerikov, Y. Trius, N. Rashevskaya, V. Tkachuk, I. Zolotareva, A. Trush, etc.), (foreign: J. Traxler, G. Dudney, V. Kuklev, H. Michian, S. Titova, A. Avramenko, etc.), and we believe that a significant advantage of mobile foreign language learning is that it promotes personalityoriented learning of students in secondary schools and provides many opportunities for differentiated, autonomous and individual foreign language learning in modern conditions.
The analysis of publications devoted to the researched question reveals unity in the views of scientists as to the fact that the use of mobile devices in a foreign language lesson helps to increase the motivation and organization of autonomous learning of students $[2 ; 3 ; 5 ; 6]$. Revealing the potential of mobile devices as a means of learning a foreign language, KV Kapranchikova notes that "regular use of mobile technologies in the process of learning a foreign language will contribute to better formation of aspects of foreign language communicative competence" [7: 93]. It should be noted that in comparison with foreign countries, in our country insufficient attention is paid to the use of the potential of mobile devices in foreign language classes.

Modernization of the educational process requires a foreign language teacher to introduce innovative pedagogical technologies into practice. In recent years, approaches to teaching a foreign language have changed significantly due to the gradual introduction of mobile technologies in the educational environment, which, combined with the inexhaustible potential of the World Wide Web, have become the basis for the emergence of mobile learning.

Mastering mobile learning allows for a more frequent use of applications for creating mind maps, which are best superimposed on the features of the mental activity of high school students, who are characterized by intense intellectual maturation.

When organizing a mobile approach to learning it is necessary to take into account the active influence of learning on the development of intelligence, will, emotions, personal needs, and if it is conducted at the appropriate level of difficulty it encourages students to think, to solve problems, and thus proceeds at a fairly rapid pace.

There are several definitions of the term Mobile learning / m-learning [7]: 
- mobile learning - is the transfer of knowledge to a mobile device (phone or laptop) using WAP or GPRS technology (i.e. the main thing is the ability to access the Internet);

- mobile learning is a technology that allows you to organize the learning process using mobile devices such as mobile phones and communicators (the ability to access the Internet is not key here);

- mobile learning is a learning process that is a type of distance learning for which knowledge is transferred to personal devices (laptop, PDA or mobile phone).

Methods of transmitting information can be varied. This form has a number of advantages:

- the learning process has no limits, which thanks to modern wireless technologies (WAP, GPRS, EDGE, Bluetooth, Wi-Fi) allows you to easily distribute learning materials among users;

- individualization of learning;

- visual learning, allows you to actively use interactive and simulated visual aids;

- promotes the interaction of the teacher with students in real time;

- gives the opportunity to receive education to people with additional needs;

- does not require the purchase of a personal computer or printed educational materials, which is economically justified;

- by presenting information in a multimedia format "promotes better learning and memorization of material, increasing interest in the learning process" [7];

- provides an opportunity to study without being tied to a specific place, and in some cases the time of classes;

- helps to perform work with the use of software in classrooms that are not equipped with computer equipment.

Despite the undeniable advantages of the introduction of mobile learning, the use of mobile devices for educational purposes has certain disadvantages too:

- lack of technical means with the necessary set of functions for some students;

- weak methodological preparation of teachers for the introduction of mobile devices in the educational process;

- insufficient amount of available mobile resources and programs for students who have different areas of educational activity;

- mobile devices provoke students to engage in various entertaining activities during the learning process (games, communication, watching video and audio resources).

Here are the specific forms and methods of implementing mobile technologies in the educational process:

- The mobile device provides access to the online resources with educational information - used as a form of distance learning. One of the most common ways to use a mobile phone in the learning process is to access the global network.

- A mobile phone is a means of playing audio, text, video, and graphics files that contain educational information. For teaching purposes special programs for cell phone platforms are used. These can open office program files, such as Office Word, PowerPoint, Excel, and text documents in various formats (txt, pdf). An example of the successful use of this method is a number of training programs in China and Japan. The mobile phone and its functionality allow you to organize learning using adapted electronic textbooks, training courses and files of specialized types with educational information - tutorials are developed directly for mobile phone platforms.

Outline of the unresolved issues brought up in the article. As was noted, the possibilities of using mobile devices in a foreign language class are very diverse. At the same time, such classes must be carefully planned. First 
of all, it is necessary to determine for what purpose smartphones and tablets will be used in class and what competencies will be formed during the implementation of the proposed tasks.

Aim of research is to identify possible and special ways of practical use of m-learning in foreign language classes in secondary school. To consider some key questions concerning methodical, pedagogical,

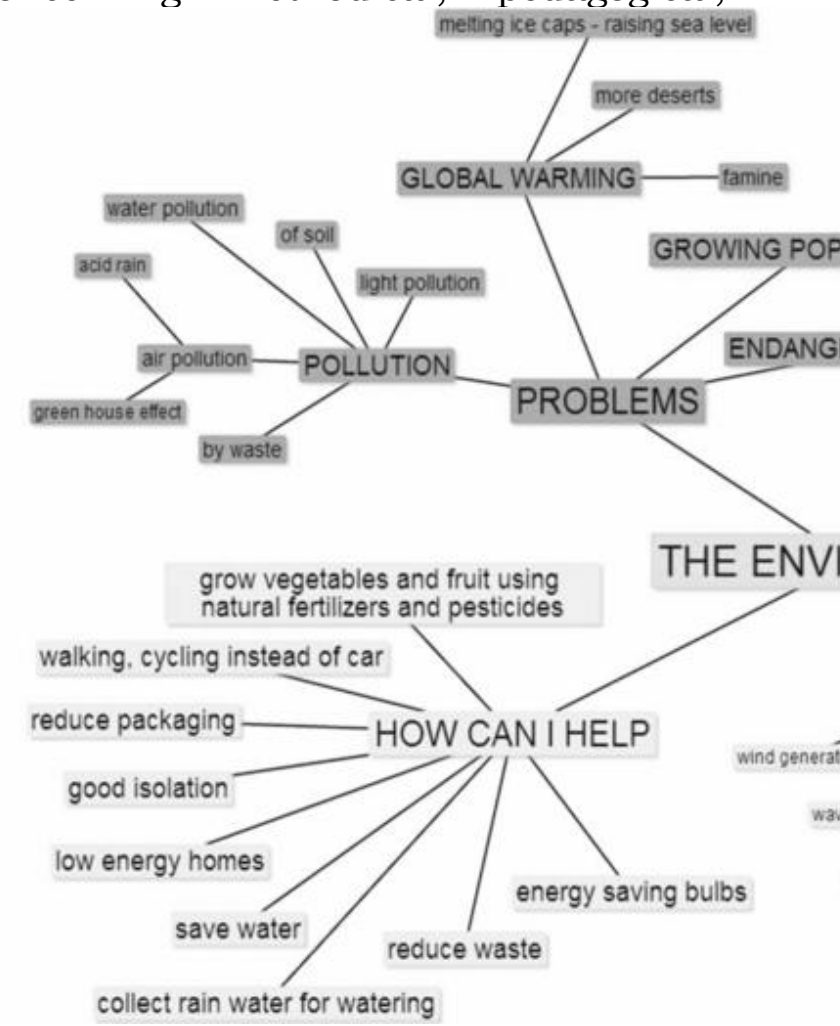

\section{Fig. 1. An example of an intelligence map created using the Simple MindFree mobile application - "The Environment"}

In addition to this mobile application, you can also use other applications to create mind maps, such as: Schematic Mind Free, Mind Meister and others.

1. MindMeister - an application for building mind maps.

- This online resource offers many opportunities to personalize your mind map (icons, fonts, styles). didactic, social, technical bases of integration of mobile technologies in teaching of foreign languages.

Results and discussion. One of the options for working with lexical material can be a creation of a mind map using the mobile application Simple Mind Free, for example: Using the mobile application Simple Mind Free create a mind map on the topic "Environmental Problems" (Fig. 1):

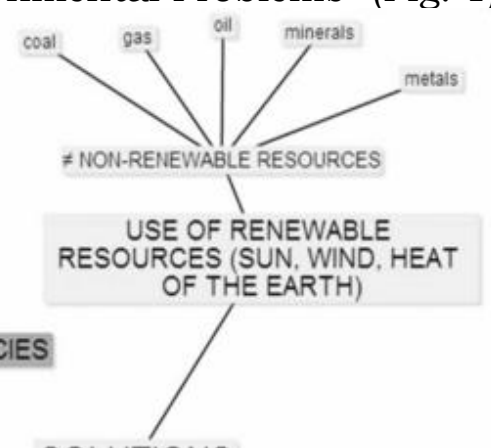
SOLUTIONS
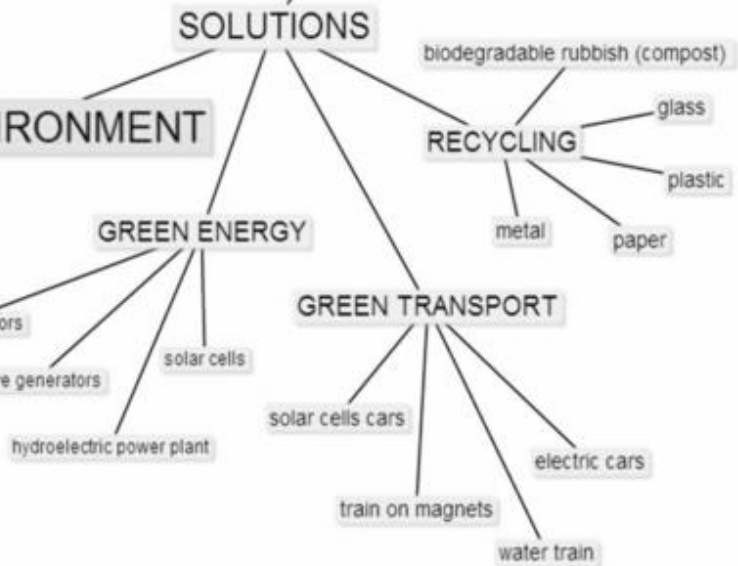

- The application supports export to pdf, rtf, jpg, gif, png).

- MindMeister has an intuitive interface and clear navigation.

- The program is free if you want to use only basic functions.

MindMeister provides the ability to edit the map by multiple users online (Fig. 2): 


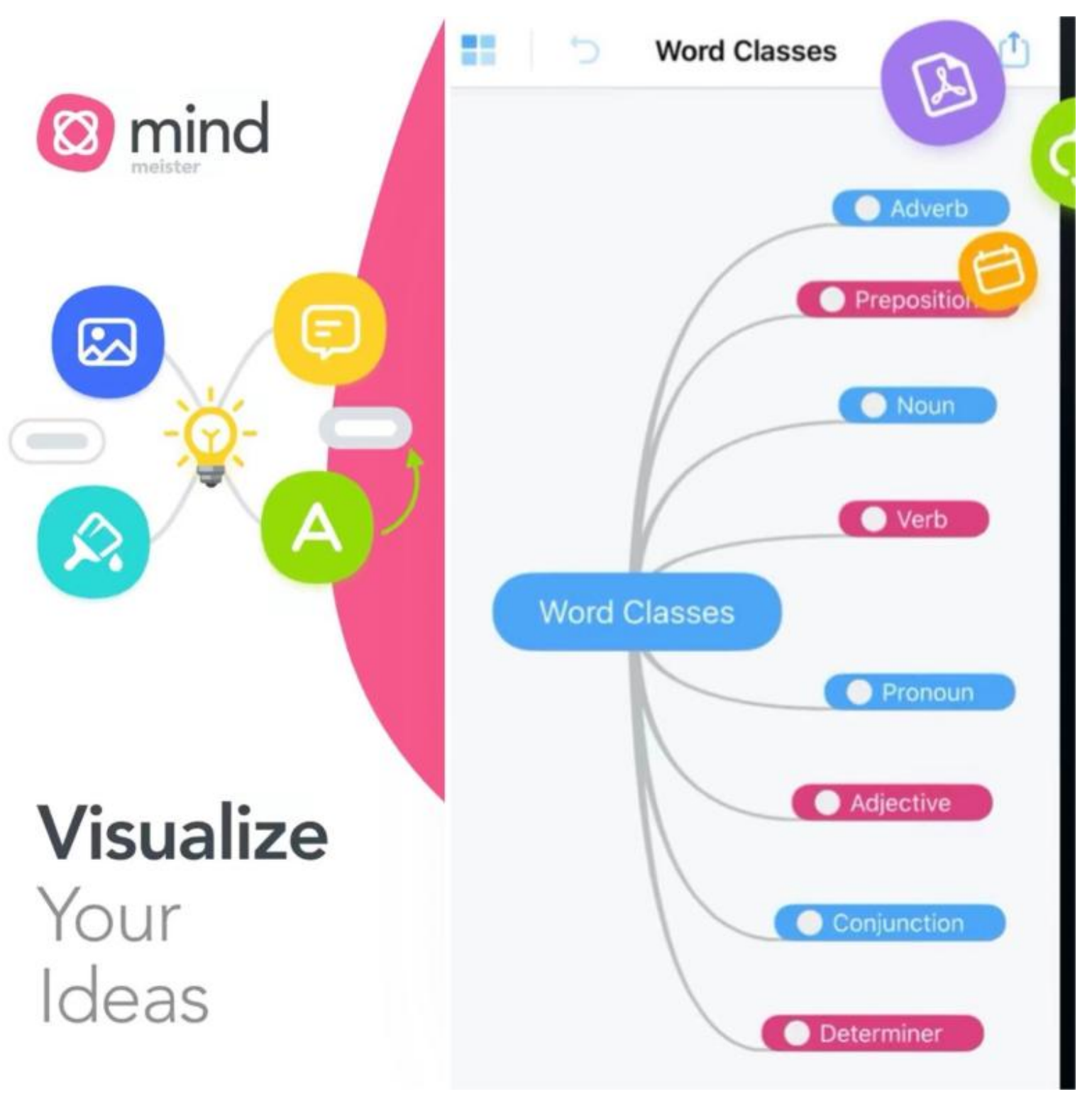

Fig. 2. The basis of creating an intelligence map using the application "MindMeister"

2. Spinscape - a powerful web application for creating mind maps.

- Has its own format Smap, also supports import from MindManager / Excel / CSV / HTML and export to Mindmanager / PDF / HTML / Word.

- Gives access to shared editing of the map in real time, as well as the ability to customize individual access to the map and its individual parts;

- Differs from other platforms for creating mind maps by its presentation mode and the ability to embed YouTube videos. 


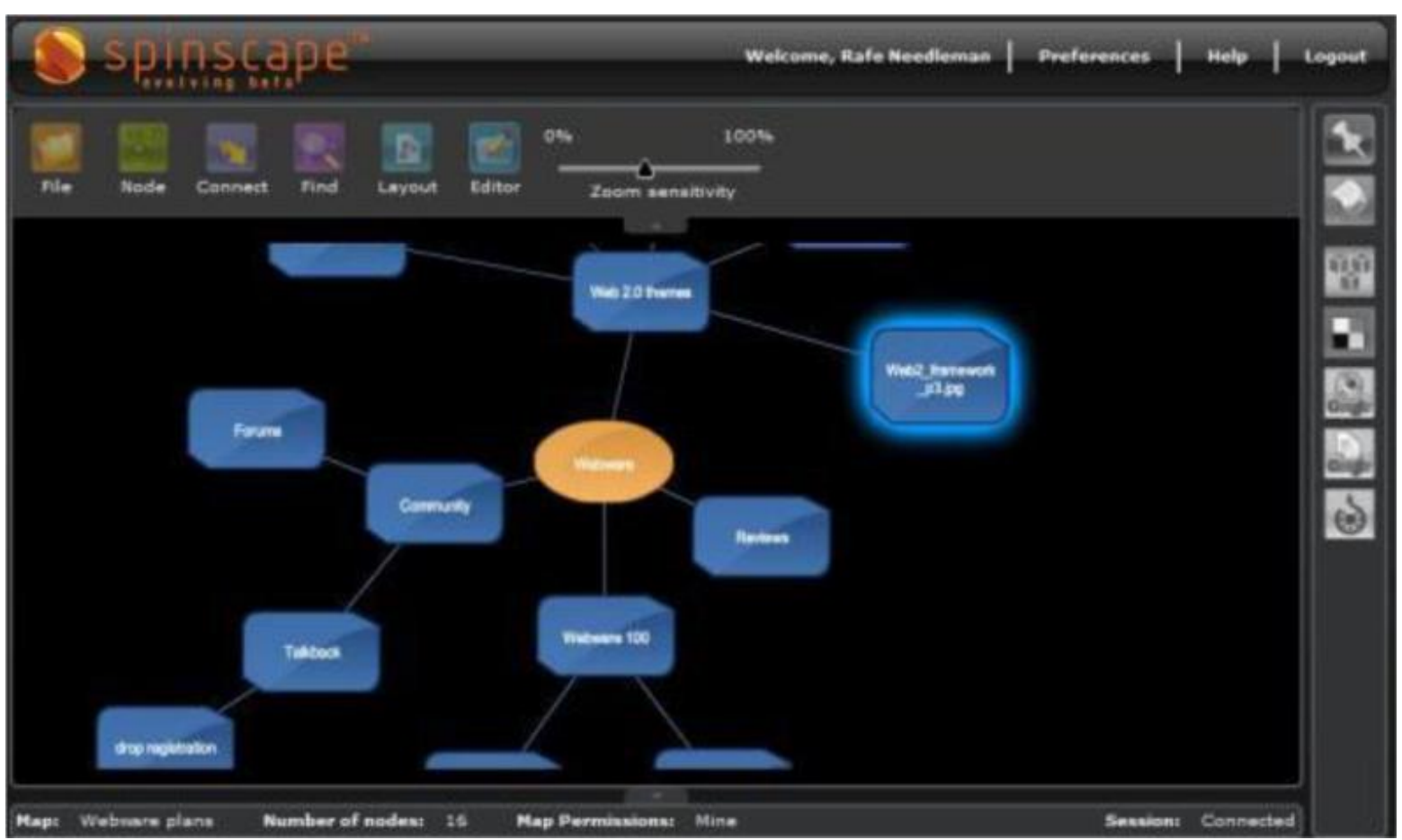

Fig. 3. Example of the basis of the knowledge map created in Spinscape

Mind map (synonymous names mental map, intelligence map, memory map, thought map, connection diagram, association map etc.) - is a way of structuring information that involves branching ideas-associations from basic concept. By creating a mental map in a foreign language class, you can work on new words on the topic or revise the familiar vocabulary. The mental map method can also be used when working with texts, as in the task: Read the text "Culture Time. Education". Use the Simple Mind Free mobile application to create a mental map for the text. On the basis of this mind map compare the education systems in Ukraine and Britain.

Here is an example of a lesson using mind maps in teaching English in the 11 th grade of a secondary school.

Detailed lesson plan-summary

Lesson №

Class: 11

Date: 07.04.18

Type of lesson: mixed

I. Purpose of the lesson.

Lesson topic: "Culture Time"

Aims:
- drill the topic vocabulary;

- develop skills of monologue speech on the topic

Goal:

1. Practical: to teach students to understand unfamiliar words based on context, to teach students to talk about "Culture Time. Education" in the scope of 10-12 sentences based on the speech situation.

2. General educational: to form the students' ideas about education in Ukraine and Great Britain.

3. Developmental: to develop intelligence, attention, visual memory of students, the ability to express their thoughts using reference schemes, memory maps, to use mobile applications for creation of the mind maps.

4. Educational: to cultivate love for the English language.

Equipment: textbook "New Destinations. B2", board, handouts (pencils, markers, colored pens, A4 paper), smartphones and mobile applications for creating mind maps.

II. The structure and content of the lesson 
Lesson stages:

1. Organizational stage ......... $2 \mathrm{~min}$

2. Main part:

- homework check .............. 6 min

- consolidation of vocabulary on the topic with the help of intelligence maps .............................. $10 \mathrm{~min}$

- development of monologue speech skills on the topic "Culture Time. Education" based on a mind map and creation of final memory maps with the help of mobile applications ...... $17 \mathrm{~min}$

3. Evaluation .................... 4 min

4. Homework assignment ..... $3 \mathrm{~min}$

5. Lesson results ................. $3 \mathrm{~min}$

Course of the lesson

1. Organizational stage

Purpose: to set students up for active speech activity.

Techniques: a short conversation about the weather and daily affairs.

Good morning, pupils. Sit down, please, and be attentive. How are you getting on? Do you like today's weather? Why yes (not)? Did anything interesting happen to you yesterday?

2. Main part:

Purpose: consolidation of vocabulary and development of monologue speech skills on the topic "Culture Time. Education System".

Techniques: performing exercises № 1, 2, Art. 3 from the appendix to the textbook; exercise with intelligence maps.

- homework check

Your home assignment was to translate words from Ex. 1 p. 3. Let's check them. Very good. Now we'll work with the verb "look" and its phrases with the help of mind-maps. I think, it'll be interesting and exciting. Take your mind-maps (see pic. 13) and work in pairs in the following way:

a) translate the phrases into Ukrainian;

b) make up sentences of your own using them; c) ask questions using the phrases;

d) make up short funny stories based on the information on the maps.

Great, you're the best. Now we'll turn to our textbooks and continue our work on the vocabulary.

- consolidation of vocabulary on the topic

Write a short dialogue with the words from Ex. 1 p. 135 and role-play it. Nice!

- creation of intelligence maps in different ways and practice in monologue speech based on intelligence maps.

We are going to create our mindmaps, the first group with the help of your smartphones, the second group with the help of pencils, pens, etc. You have only $10 \mathrm{~min}$.

We are going to practice our monologue speech skills by working with the mind-map "Culture Time. Education". Follow the steps.

1. Look at the map of "Culture Time. Education" and describe it using the vocabulary below the map. Work in pairs.

2. Read the short passage about "Culture Time. Education System" and translate it.

3. Ask questions about the education systems and describe the pictures.

4. Act as an expert. Tell about the education systems in the UK and UA.

5. Make up a short dialogue "Education System in my Country".

6. Work in groups and ask questions about the education systems in the UK and UA.

7. Put aside the mind maps and try to reproduce the maps themselves from your memory.

3. Evaluation.

Dear pupils, you have worked very hard. So, your marks for this lesson ...

4. Hometask. 
Вісник Житомирсъкого державного иніверситети імені Івана Франка. Педагогічні науки. Bun. 3 (102)

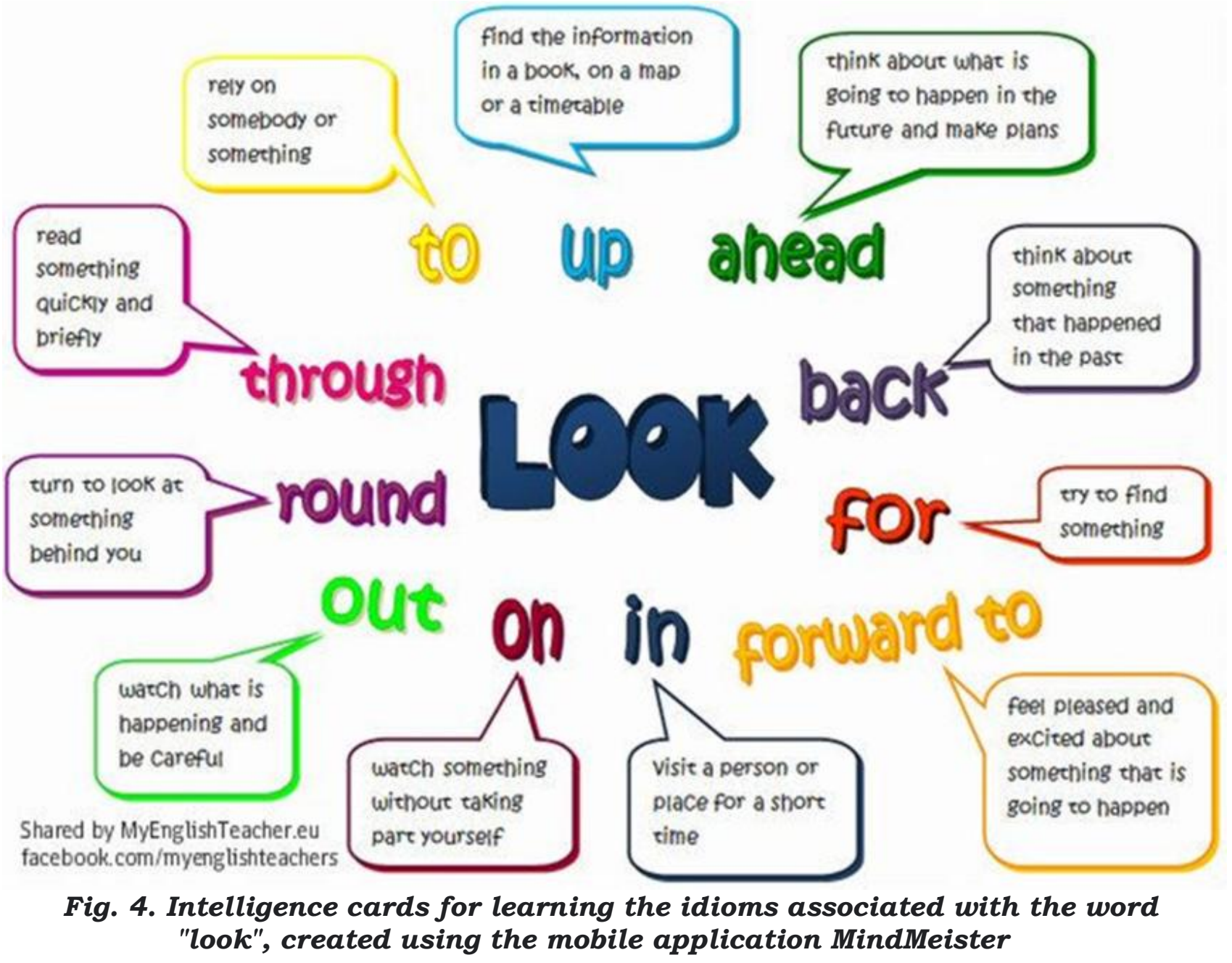

Your home assignment will be to finish working with the mind map "Education System" (drawing a map of your own and reproducing it afterwards) and write a short story with the words from Ex. 4.

5. Conclusion of the lesson.

I believe you have learnt a lot of interesting things about the education systems in epy UK and UA. Besides you have become familiar with the verb "to look" and its phrasal verbs. As you see the mind maps help us remember the material better. So practice doing them at home.

Mind-map is an example of easy and effective technique in the educational process, which requires a minimum of effort and time, but brings the most positive result, and with the help of mobile applications, the process of creation and memorization becomes even faster and more efficient.

The experiment involved 18 students of 11th grade (control (CG) and experimental (EG) groups) - 9 students in each group. EG used the above mentioned mobile applications to create intelligence maps (Fig. 5, 6, 7). CG used traditional methods of creating memory cards (Fig. 8, 9, 10). Both groups worked with the textbook "New Destination. B2" and studied the same material. At the final lesson, students were asked to create intelligence maps for the studied topic "Culture Time. Education". 


\section{Education}

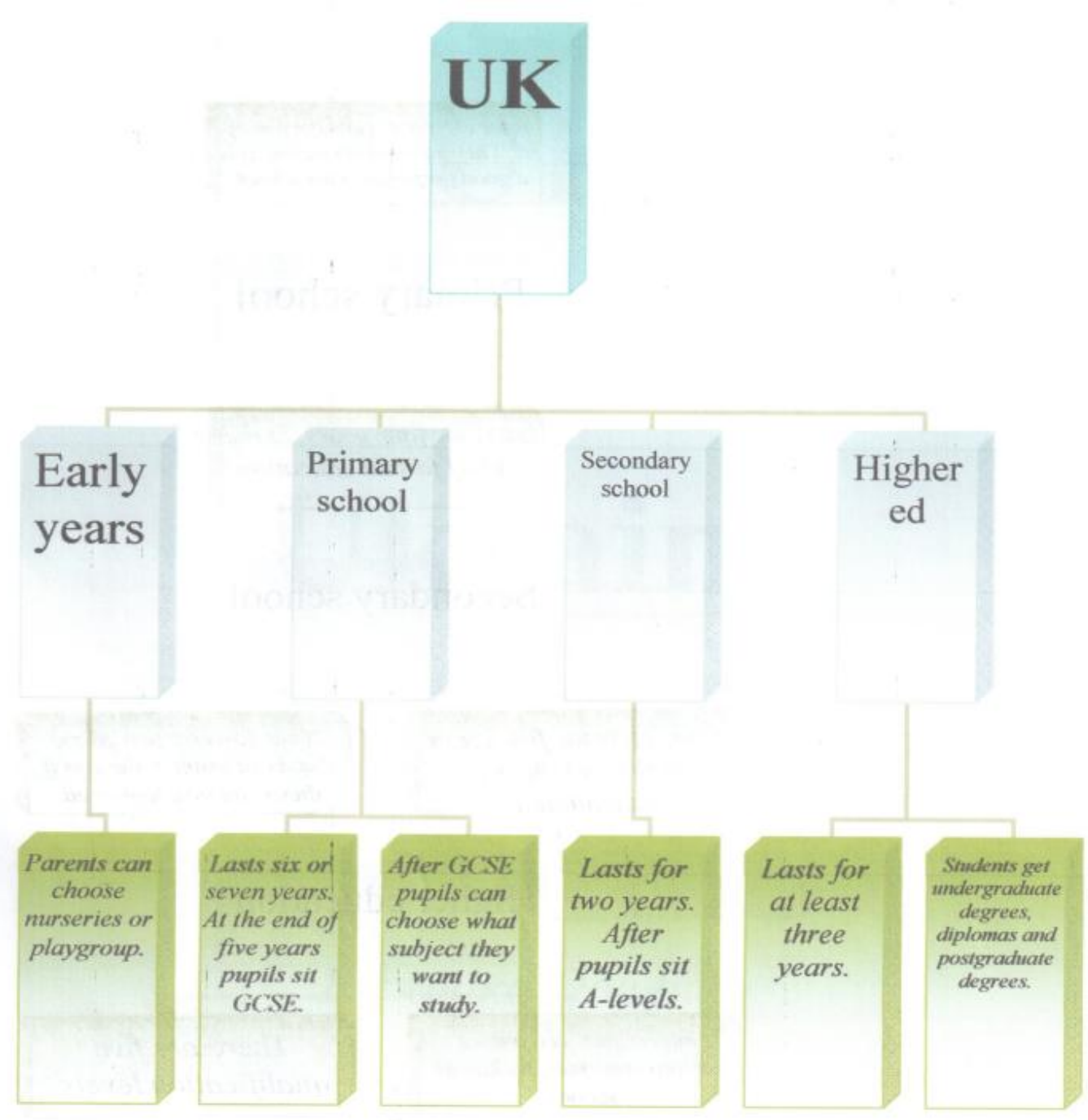

Fig. 5. Mind-map to "Culture Time. Education in the UK" 


\section{Ukraine}

Preschool education

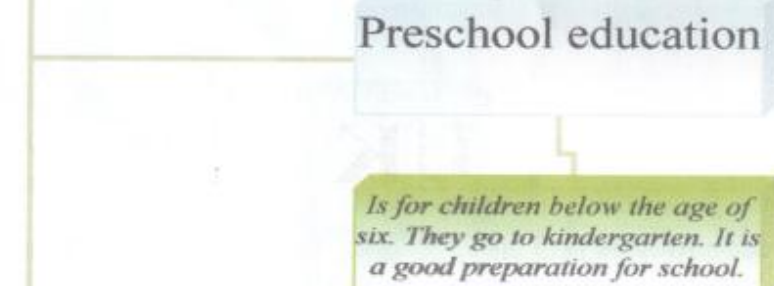

Primary school

Lasts for four years. Is the start of formal education.

Secondary school

Ifase: lasts for five years. At the end there is examination.

\section{Higher education}

Universities, academies, various institutes, technical school.
2 fase: lasts for two years. Pupils sit exam at the end if they want take higher ed.

Fig. 6. Example of mind-card "Culture Time. Education in Ukraine" 


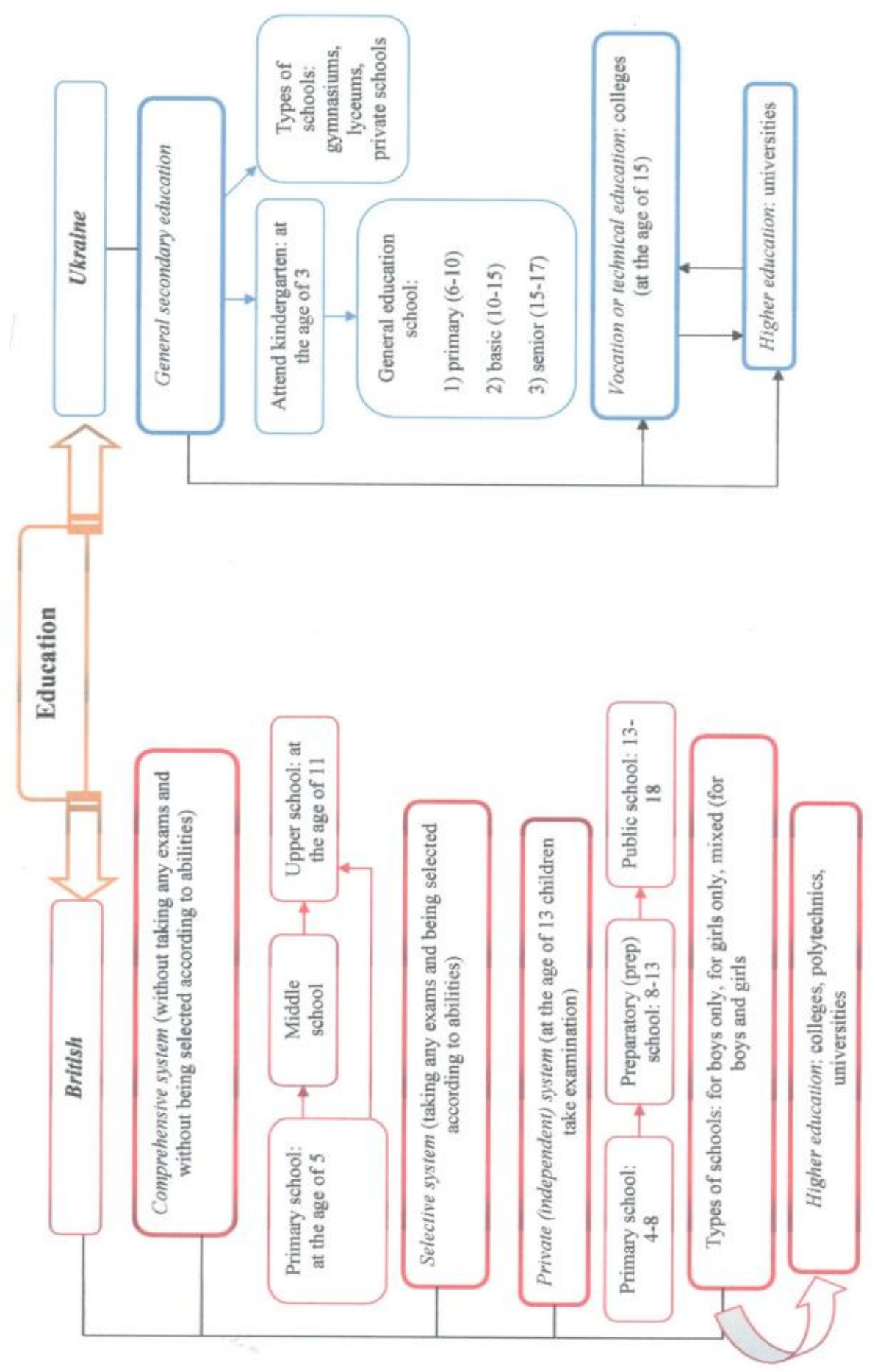

Fig. 7. Intelligence map "Culture Time. Education in Uk vs UK" 


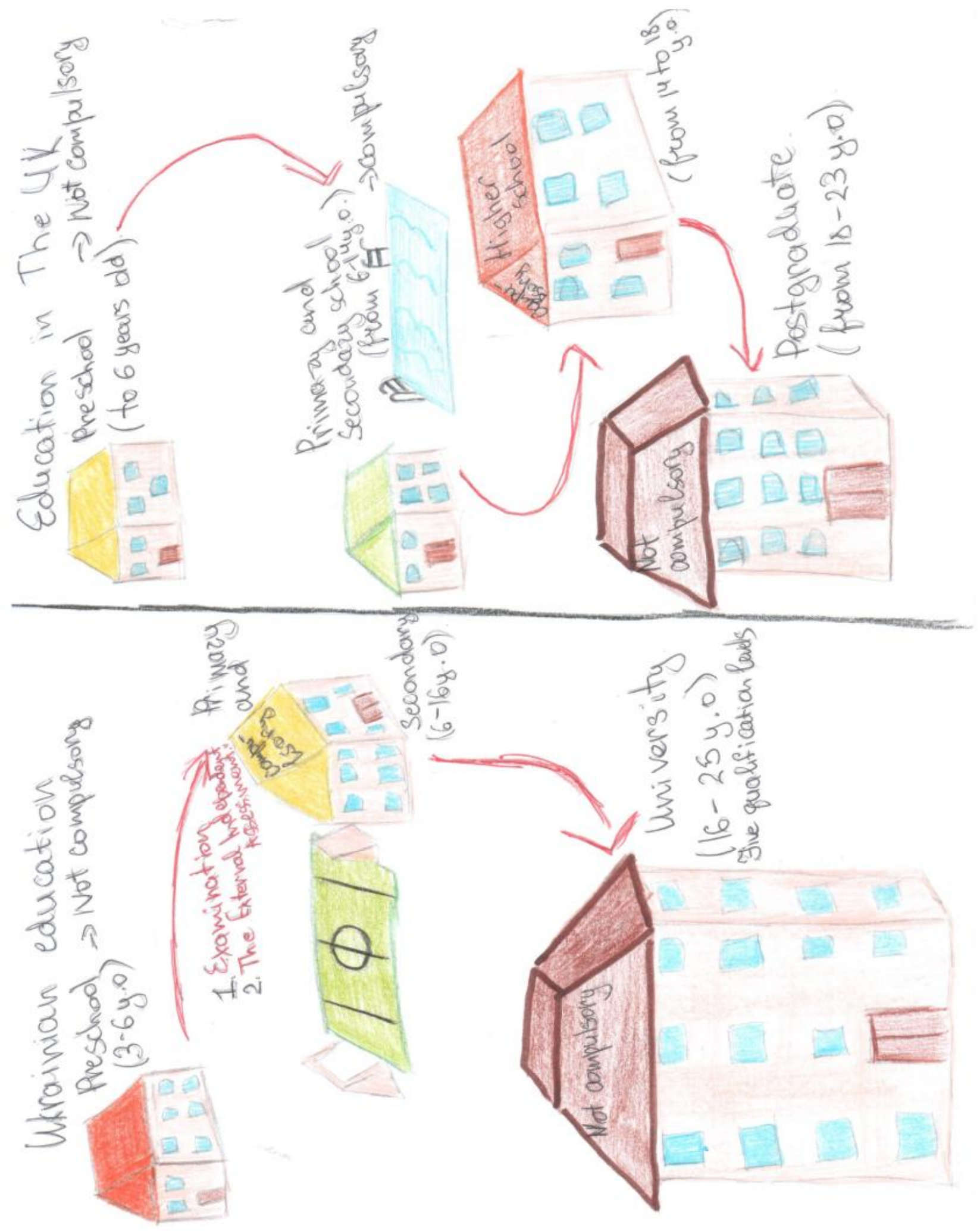

Fig. 8. Mind-map "Culture Time. Education in Uk vs UK" 


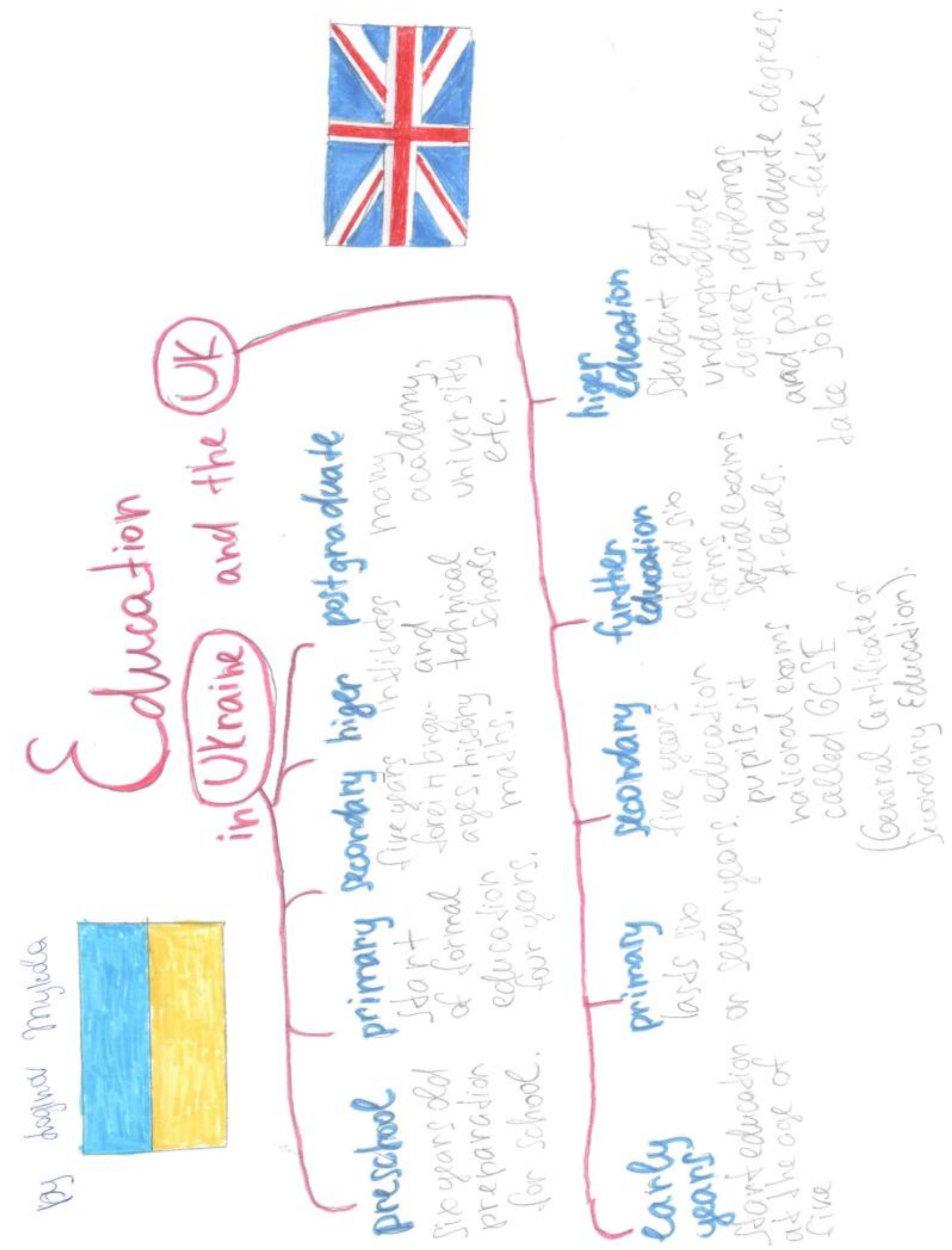

Fig. 9. Mind-mind "Culture Time. Education in Uk vs UK" 


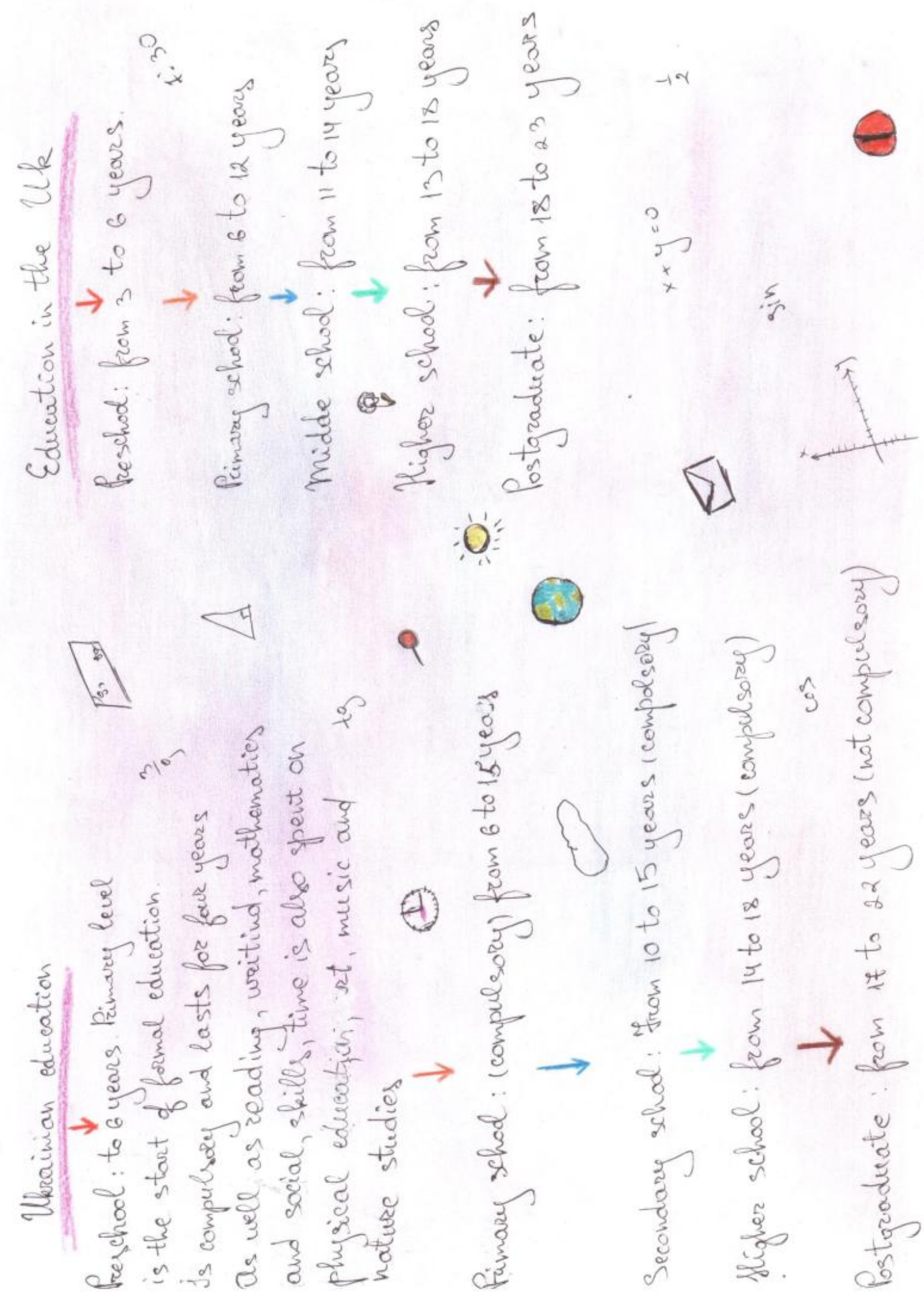

Fig. 10. Mind-map "Culture Time. Education in Uk vs UK" 
Thus, the results of the control section conducted after the introduction m-learning in the process of teaching English in the 11th grade of secondary school № 12 in Ternopil allow us to conclude that in the experimental group in contrast to the control group there were qualitative changes: the number of students with a high level of knowledge increased (students, who used mobile applications to create intelligence maps, coped with the task faster and reproduced in more detail the previously studied material), which testifies to and confirms our hypothesis of global mobilization of the younger generation, which will potentially improve learning.

Mind-maps make it possible to individualize the learning process and increase its effectiveness and turn it into developmental learning.

The technical equipment of mobile devices, namely the built-in camera, allows students to offer tasks that will contribute to the development of communicative competence. One such task may be to record an interview on a given topic, namely: "Make a film on the topic: History of My School". Create groups of three participants (student, journalist, cameraman). Choose one of the following topics for your group: "My School", "Our Teachers", "Our Students", "Our Classrooms", "Our School Life". Record an interview in the group on a selected topic. Combine the interviews of all the groups into one film and show it to your classmates.

In the course of the research it was found out that mobile learning of a foreign language was implemented in lessons and during extracurricular independent work of students in the form of:

- translation of texts using an electronic dictionary;

- watching video and listening to audio in a foreign language online;

- demonstration of presentations, slide shows, mini-movies and clips;
- search for the necessary information on the topic;

- online testing;

- use of various applications for more effective learning of a foreign language;

While researching applications in which the user can independently develop material for learning we found out that their numbers are few. This feature can be found in LinguaLeo, where the user can compile their own vocabulary with sound. Most applications belong to both the second and third type - Duolingo, Busuu, Rosetta Course, Byki, Polyglot and more. They present ready didactic material in the form of cards, texts, audio and video fragments. Next, it is proposed to study the initial material in the form of various exercises. By collecting points to move to the next level, the user is motivated to study the proposed material. Users can also compare their achievements and share successes on social networks. Some applications provide an opportunity to take an entry test, based on which users will be offered recommendations to help start learning. As for the interface language, there are almost no Ukrainian-language programs. They mainly offer applications in Russian or English. In some applications, the training itself is conducted in a foreign language, which significantly increases the effectiveness of the course. In almost all applications, the material is divided thematically, which allows you to easily find information on the topic [8].

Conclusions and research perspectives. The requirements of the modern information society for the globalization of knowledge, timely access of anyone to information sources, to the informatization of the educational process, create the preconditions for the introduction of $\mathrm{M}$ learning technology in our country.

Mobile devices have become an integral part of our lives and each succeeding generation is showing more 
and more interest and need for their daily use. The programs that can be downloaded on them provide an opportunity to improve knowledge and develop language and speaking skills in any convenient place and at any time. Using such applications in the classroom will help students get new learning material in various forms (cards, pictures, audio, video and even in the form of games), process it and revise at any time. The motivational aspect also cannot be ignored: students can compare their results and compete, while learning a foreign language.

Thus, the introduction of mobile learning contributes to the implementation of personality-oriented learning of a foreign language, improving research skills of students, as well as the development of teamwork and cooperation skills, which will contribute to the formation of foreign language communicative competence of students.

The prospect of research on this topic is a more detailed study of the types of mobile applications, their capabilities and the development of methods for their practical use in foreign language lessons.

\section{REFERENCES (TRANSLATED \& TRANSLITERATED)}

1. Andreev, A.V., Andreeva, S.V., \& Dotsenko, I.B. (2008). Praktika elektronnogo obucheniya s ispolzovaniem Moodle [E-learning practice with Moodle]. Taganrog: TTI YuFU [in Russian].

2. Golitsyina, I.N.,

$\&$

Polkovnikova, N.L. (2011). Mobilnoe obuchenie kak novaya tehnologiya $\mathrm{v}$ obrazovanii [Mobile learning as a new technology in education]. Obrazovatelnyie tehnologii $i$ obschestvo - Educational technology and society, № 3, 56-64 [in Russian].
3. Goryunova, L.V. (2013). Mobilnost kak printsip modernizatsii vyisshego pedagogicheskogo obrazovaniya [Mobility as a principle of modernization of higher pedagogical education]. Izvestiya Yuzhnogo federalnogo universiteta. Pedagogicheskie nauki - Bulletin of the Southern Federal University. Pedagogical Sciences, № 6, 237-242 [in Russian].

4. Kilkist korystuvachiv smartfoniv $v$ Ukrayini zrosla na $150 \%$ [The number of smartphone users in Ukraine increased by 150\%]. www.epravda.com.ua. Retrieved from https://www.epravda.com.ua/news / 20 16/09/12/605197/ [in Ukrainian].

5. Kuvshinov, S.A. (2007). MLearning - novaya realnost obrazovaniya [M-Learning - the new reality of education]. Vyisshee obrazovanie $v$ Rossii - Higher education in Russia, № 8, 59-63 [in Russian].

6. Orlov, S. (2012). CitrixSynergy 2012: oblaka i mobilnost [CitrixSynergy 2012: Cloud and Mobility]. Zhurnal setevyih resheniy LAN - LAN Networking Journal, № 11 . Retrieved from http: / /www.osp.ru/lan/2012/11/1303 2372 [in Russian].

7. Birkenkrahe, M., DimitriSchild, D., \& Trofimov, V. (2012). UNIVERSITY 2.0. Part of the IADIS Multi conference on computer science and information systems 2012: IADIS International conference $e$ Learning 2012, Lisbon, Portugal [in English].

8. Petryk, A. (2013). 10 mobilnyx dodatkiv dlya vyvchennya inozemnoyi movy $[10$ mobile applications for learning a foreign language]. Retrieved from

http: / /www.uamodna.com/articles / 10mobiljnyh-dodatkiv-

dlyavyvchennyainozemnoyi-movy/ [in Ukrainian]. 